\title{
The Facelessness of Evil: Towards a Rationale for Corporate Criminal Liability
}

\author{
By Clément Labi ${ }^{*} \&$ Willy Tadjudje
}

\begin{abstract}
Why do we assign ethical intentions or mechanisms to certain businesses, which by design do not possess intentionality in the same way as actual businesspeople do? Are these merely opportunistic shortcuts from the judges or the law, in search of sizeable assets to implement reparation or levy a fine? On the contrary, the article will attempt to describe how the unethical aspect of some decisions could not be satisfactorily explained in terms of the intentions of individuals, but rather as being the products of the value system, or corporate culture, proper to the legal entity itself notably because the sense of individual responsibility is diluted and scruples assuaged. Therefore, not only can businesses in themselves can be assessed in terms of ethics, but the reality of a literally faceless business is congruent to institutionalised wrongdoing.
\end{abstract}

Keywords: Ethics; Criminal Law; Criminal Liability; Legal Personality.

\section{Legal Persons and the Riddle of Responsibility}

Our first notions of legal responsibility rely on the individual. One is supposed to assume the damages caused to third parties. Complexification of activity and life has hastened the evolution of the concept.

Usually, responsibility is either civil or criminal. In any case, the responsibility relies on the individual, but in criminal matters, there is exceptional consideration for intention.

The classical notion of legal responsibility tries to approximate moral responsibility mostly conceptualised in terms of individual morals. French law underlines the notion of "responsabilité du fait personnel - personal liability", to characterise this aspect. Indeed, since the reform of the Law of Obligations which came into effect on $1^{\text {st }}$ October 2016, the former article 1382 of the Civil Code, which became article 1240, lays down the principle of personal liability:

"Any act of man [human being or person], which causes damage to another person, obliges the person through whose fault it occurred to make reparation for it."

In other words, when the fault of a person causes damage to any victim, the person responsible must compensate the victim.

\footnotetext{
* PhD Candidate, Faculty of Law, Economics and Finance, University of Luxembourg, Esch-surAlzette, Luxembourg. Corresponding author. Email: clementlabi@gmail.com. ${ }^{ \pm} \mathrm{PhD}$ (Law), Lecturer, Faculty of Law, Economics and Finance, University of Luxembourg, Eschsur-Alzette, Luxembourg, Email: willytadj@gmail.com.
} 
The cause of liability may be multiple, but in general, the element that attracts attention is that of wrong ${ }^{1}$. Anyway, three conditions are necessary to engage personal liability under French law:

a) A wrong: such a person did not behave as a "bon père de famille/good father": he/she did not act as a normally prudent and diligent person would have done in the same circumstances.

b) Damage (material and/or moral).

c) A causal link between the wrong and the damage: there would have been no damage if the wrong had not been committed.

If these three conditions are met, the wrongdoers must repair for the harm he they caused to others by their behaviour.

The mere fact of being the victim of damage is therefore not sufficient to obtain compensation: such damage may in fact result from an unfortunate combination of circumstances, without anyone having committed the slightest wrong.

Mostly in criminal law, responsibility is very intensively linked to the notion of intention. Under French law, criminal responsibility implies the three constituent elements: a text of incrimination (legal element), a conduct sanctioned by the text (material element) and the involvement of the perpetrator in the commission of the conduct punished (intentional element) ${ }^{2}$.

The criminal infraction is that deed committed with criminal intent. Therefore, in most jurisdictions, the action committed under duress, or in a state of abolition of consciousness, is not criminal. These motives of exculpations are less powerful in non-criminal matters.

However, even in criminal law, arrangements are being found when intention is lacking. At that point, three examples will be given as illustrations.

In the United States, the Supreme Court would demand proof of mens rea when a criminal infraction is alleged. However, the requirement would not follow if the rule being violated was deemed to be "regulatory" in nature ${ }^{3}$. The Court stated that no evidence of mens rea was needed since the law at stake was "a regulatory measure in the interest of the public safety, which [could] well be premised on the theory that one would hardly be surprised to learn that possession of hand grenades is not an innocent act. ${ }^{4}$, evidently establishing a confusion between the requirement for a criminal intent and the principle that ignorance of the law should not be exculpatory.

\footnotetext{
${ }^{1}$ Namely the breach of duty (individuals owe duties to each another, when breached, they need to restore the status quo by means of reparation), the freedom or liberty (individuals are granted liberty or their liberty is acknowledged. But liberty also means that they should be held responsible for their actions), the wrong (similar to breach of duty but with a more pronounced moral aspect), the authority or custody, the command, etc.

${ }^{2}$ Bouloc (2019).

${ }^{3}$ Cass (1976).

${ }^{4}$ United States v. Freed, 401 U.S. 601 (1971).
} 
Similarly, French law used to state that there could be no criminal intention where there existed an "invincible error as to the Law". A corporation planned a transaction and asked the Ministry of Economy for an advice on whether this could be considered a violation of the anti-trust provisions of the Criminal Code: they were informed that it would not. However, the Court still convicted the company on the grounds that the company had the means to consult with a "quality lawyers" who should advise that the Ministry's advice was erroneous 6 .

Furthermore, alcohol diminishes discernment, sometimes to the point of abolition of consciousness: however, the law generally requires that the intoxicated state should not be "self-induced", which should not be a criterion as to the intent of the accused, and is in practice almost never met ${ }^{7}$.

The intentional element is therefore not verified in all cases. In the first example, the company arranged to seek information from the Ministry, but obtained bad advice that caused harm to others (an anti-trust violation).

Similarly, the notion of individual responsibility tries to move closer to moral responsibility. If one has harmed another by using means that may aggravate the commission of the offence, it is right that the punishment should be corresponding.

Consequently, it appears very clearly that even in criminal law, the intentionality requirement is not always scrupulously respected. For the time being, we should content ourselves with the proposal that criminal responsibility of legal persons is not a more "artificial" or "opportunistic" concept than civil liability applied to the same entities. In some sense, furthermore, repressive systems have themselves toyed with the Aristotelian concept of penal retribution for quite a long time. If, as it is classically proposed, criminal intent is quintessential to the offense itself, how would it be justifiable that an altered state of consciousness does not at the very least diminish the extent of the punishment? How could one account for the over-representation of the mentally ill in the prison population $^{8}$ ?

Therefore, one could either keep the definition of a crime on the metaphysical plane, and accept the dreadful consequences of retaining intention as an authentic criterion, or (and this is the only intellectually defensible alternative) consider that criminal had a function, and maybe implicitly accept that any principles are therefore pre-empted by the purposes, whether they be those stated by Lombroso ${ }^{9}$ or by Foucault ${ }^{10}$. At any rate, the same set of criteria could not explain the simultaneous existence of the infractions of manslaughter and murder.

The Industrial Revolution has provoked a revolution of its own as it shattered, in many instances, the individual and intentional stall marks of legal responsibilities, thus provoking an intellectual crisis which goes as deep as our very conception of what our ethical duties consist in.

\footnotetext{
${ }^{5}$ Article $122-3$ of the French Criminal Code.

${ }^{6}$ Cass. Crim. 19/03/1997.

${ }^{7}$ Herald (1970).

${ }^{8}$ Bechler (1988).

${ }^{9}$ Lombroso (1911).

${ }^{10}$ Foucault (1975).
} 
Analysis of tort law in three systems from the antiquity seems to reveal a discrete agreement that responsibility is based on the breach of the duty of man. In Jewish law", the principle is promulgated in the Talmud as "I am liable for the acts of anything which I am under a duty to guard". In English law, the four principal elements of negligence are: a duty of care, breach of that duty, a breach causing harm, and said harm being not too remote, as a consequence of the breach $^{12}$. French law also requires the simultaneous existence of a faute (which came to be defined very quickly in literature and by the courts as the objective breach of a legal obligation), damage, and a causality between the two ${ }^{13}$. Imperceptibly, however, these legal systems took with the extent to which a violation of duty was required to characterise responsibility. An excellent example is provided by the evolution of French Case-law on strict liability in case of "responsabilité du fait des choses" (damages caused by things instead of by a "personal fact"). Let us start with a textual comparison of the relevant provision of the Napoleonic Code as they were originally enacted.

Article 1382 provided that:

"Any deed whatever of man that causes damage to another, obliges him by whose fault it occurred to repair it."

This is complemented by Article 1383:

"One is responsible not only for the damage occasioned by our own act, but also by our own negligence or imprudence."

When providing for the legal regime of the damages caused by things

"One is responsible not only for the damage caused by their own act, but also for that which is caused by the acts of persons for whom they are responsible, or by things that are in their custody."

It is therefore obvious that Article 1384 only continues the principle of Article 1382. However, starting in the $19^{\text {th }}$ century, French-case-law rediscovered Article 1384 as a source of responsibility with no requirement of a faute ${ }^{14}$, which literature correctly construes as a response to the growing issue of workplace incidents, and as a cornerstone of the early building of the French welfare State ${ }^{15}$.

\section{The Responsibility of the Legal Entity}

Perhaps the second-most difficult concept to comprehend is the one of the responsibility of the legal entity.

\footnotetext{
${ }^{11}$ Lieberman (1927).

${ }^{12}$ Deakin, Johnson \& Markesinis (2003).

${ }^{13}$ Terré, Simler, Lequette \& Chénedé (2018).

${ }^{14}$ Ibid.

${ }^{15}$ Ewald (2020).
} 
Professor Talbot, whose expertise is in UK company law, traces back the concept of corporate liability to, paradoxically, that of limited liability of the shareholders. The point she makes can be summarised as follows: case-law started by recognizing that shareholders were only liable for the investment they had actually made in the company. Therefore, creditors would not have had any chance to recover their receivables, if not through the acknowledgment (or invention) of full legal personality of the corporation itself, thus allowing for the identification of corporate assets that could be seized. ${ }^{16}$ In parallel, the same intellectual movement led to the understanding that companies could bear liabilities the same way that natural persons do.

There are of course excellent practical reasons why this should be, and the existence of corporate liabilities are desirable for even their members. For instance, when granting a large-scale loan, a bank would much rather have a corporation be the borrower than dealing directly with the investors (insofar as, in most cases, the bank offers more solid assets and future cash flows) said investors would of course much rather have "their" corporation assume the liabilities, lest the very principle of limited liability loses entirely this meaning. ${ }^{17}$ However, even this modest arrangement is actually quite difficult to justify from a theoretical standpoint: if the corporation does indeed possess full legal personality, how could it incur responsibility either for agreements signed by officers or for torts caused to third parties? The unifying concept of representation does not here serve as a panacea, as some limit cases show to evidence: for instance, some actions taken by the future directors before the incorporation of the company can be transformed into the company's own after the company is set up; on the contrary, statutory limitations to the power of the directors cannot, classically, be opposed to third parties acting in good faith. For the sake of clarity, we are obviously not arguing here that directors should not be able to generate responsibilities for the company they represent, however we do argue that the concept is not devoid of problematics, if only because, while natural persons might appoint an agent to take action in their name and on their behalf, the agents of the company are in actuality appointed not by itself but by its shareholders, or in some cases, even by its already appointed directors ${ }^{18}$ (creating a recursive logic issue that, to the best of our knowledge, has not been satisfactorily resolved).

\section{The Rationale for Criminal Responsibility of the same Legal Entity}

The most difficult question altogether is the rationale for criminal responsibility of the same legal entity. We saw earlier how most legal systems dissociated civil responsibility and intent, for instance associating it with risk and sometimes with the idea of guarantee. Nevertheless, the same legal systems demand, in principle, that intentionally be characterised whenever finding a person guilty of committing a criminal offence.

\footnotetext{
${ }^{16}$ Talbot (2015).

${ }^{17}$ Merle (2020).

${ }^{18}$ Davies, Hopt, Nowak \& van Solinge (2013).
} 
Hence, the relatively recent invention of the criminal responsibility of legal persons can be justified by a teleological approach, but remains challenging from the point of view of the principles. Few even attempt to explain it by reasons other than mere opportunism. Among those few, Clarkson, sketching the outline of what corporate mens rea, writes the following ${ }^{19}$ :

"companies can be conceived as culpability-bearing agents who 'act' through their offices and employees and whose 'mens rea' is to be found in their corporate practices or policies [...] both recklessness or intention can also be found in a company's policies, operational procedures and lack of precautions. If the corporate culture permitted or encouraged the wrongdoing, it may be easy to infer that the corporate body itself must have foreseen the possibility of the harm occurring [...] or that it has created an obvious and serious risk of the wrong resulting [...] or that the consequences was virtually certain to occur from which intention may be inferred. The important point about this approach is that it is not whether any individual within the company would have realised or foreseen the harm occurring but whether in a properly structured and organised careful company the risks would have been obvious."

Our intent is not to nit-pick a theory that tries to grasp with such an elusive concept, but we fear that there might somewhat of a petitio principis in the acceptance that companies literally act although the author uses quotation marks) through offices and employees; the policies can reflect mens rea and essentially the corporate body is identified with the company itself.

However, it does make an excellent point about corporate culture which will serve as the basis of our own proposal, as further detailed below.

It is thus no surprise that the opinion of the Supreme Court of the United States validating the concept of corporate criminal liability should be so disappointing. Predictably, after recalling that a company can be responsible for the actions of its employees and other agents, Justice Day very succinctly and unconvincingly uses opportunity as an explanation:

"It is true that there are some crimes which, in their nature, cannot be committed by corporations. But there is a large class of offenses, of which rebating under the federal statutes is one, wherein the crime consists in purposely doing the things prohibited by statute. In that class of crimes, we see no good reason why corporations may not be held responsible for and charged with the knowledge and purposes of their agents, acting within the authority conferred upon them. [...] If it were not so, many offenses might go unpunished and acts be committed in violation of law where, as in the present case, the statute requires all persons, corporate or private, to refrain from certain practices, forbidden in the interest of public policy, ${ }^{20}$ (emphasis ours).

This is uttered after sweeping under the rug Blackstone's advice that "A corporation cannot commit treason, or felony, or other crime in its corporate

\footnotetext{
${ }^{19}$ Clarkson (1988).

${ }^{20}$ New York Central \& Hudson River Railroad Co. v. U.S, 22 Ill.212 U.S. 481, 29 S. Ct. 304, 53 L. Ed. 613 (1909). Emphasis ours.
} 
capacity, though its members may, in their distinct individual capacities"21 and quoting approvingly the clearly tautological argument, contained in Bishop's New Criminal Law, and according to which:

"Since a corporation acts by its officers and agents, their purposes, motives, and intent are just as much those of the corporation as are the things done. If, for example, the invisible, intangible essence or air which we term a corporation can level mountains, fill up valleys, lay down iron tracks, and run railroad cars on them, it can intend to do it, and can act therein as well viciously as virtuously. ${ }^{22,}$

\section{Are Legal Persons only Responsible by Default?}

A legal person acts through individuals and that is the reason why they are only responsible by default. In liability law, in addition to personal liability, which is the most classic, there is also vicarious liability. The latter has several facets, including, in French law, the liability of principals for the acts of employees (responsabilité des commettants du fait des préposés). It is this aspect that is most closely related to liability in corporate law. In reality, even the so-called unipersonal company, by virtue of its legal personality, is not comparable to an individual who may act intentionally.

However, in corporate law, we are witnessing an excessive extension of the scope of vicarious liability. In practise, boards purposefully dilute responsibilities. At any rate, the framework for the responsibility of legal persons needs more clarification collectivised crime needs organised irresponsibility.

For many reasons, strict vicarious criminal liability corporations appears at first sight unfair, at least because "it subjects a corporation to criminal liability when a single rogue employee engages in misconduct - even if the misconduct directly violates the corporation's policies and occurs despite a rigorous compliance program. As a result, a single errant employee can cause the downfall of a multi-national corporation and the loss of thousands of jobs" 23 .

We will here make a case on why the criminal responsibility of the corporation could be accepted as said corporation is an environment set in place so that individual responsibilities are erased.

Corporation law functions upon the principle of limited liability. ${ }^{24}$ This is obviously true for shareholders, whose exposure is generally limited to the amount of their investment in said corporations. "The no-obligation, no-responsibility, noliability nature of corporate shares permits their owners - or their institutional representatives - to enjoy income rights without needing to worry about how the dividends are generated. They are not legally responsible for corporate malfeasance and in the event of failure only their initial investments are at risk",25.

\footnotetext{
${ }^{21}$ Blackstone (1765).

${ }^{22}$ Bishop (1893).

${ }^{23}$ Ibid.

${ }^{24}$ Kraakman, Hansmann, Pargendler, Hertig, Kanda \& Davies (2004).

${ }^{25}$ Ireland (2010).
} 
However, directors pursue the same strategy: they seek eternally to diminish their responsibility, notably through the means of $\mathrm{D} \& \mathrm{O}$ insurance, but also by mixing their decisional power with those of the other directors and stakeholders in the company. No one likes risks for the sake of risk ${ }^{26}$.

Empirically, it is often a difficult task to find one or several persons who can in all honesty be held individually/jointly liable for the damages caused by/in the interest of/ in the name of the corporate structure. In fact, "courts generally hold that a corporation is subject to strict vicarious liability for a criminal act by one of its employees if the employee acted within the scope of his employment and intended, at least in part, to benefit the corporation"27. The concept of intention guides the analysis of the judge in this perspective. That is why "even if the corporation did not receive any financial benefit from an employee's crime, it will still be subject to strict vicarious criminal liability if the employee intended, in part, to benefit the corporation" 28 .

Oftentimes, the best reasoning judges can cling to be the failure of a director or officer to do something: by their inaction, they have caused a catastrophe. They literally did nothing - therefore falling to a bias according to which action is always better than a lack of action. Consequently, "the theory of strict vicarious criminal liability for corporations that has prevailed in the federal courts of appeals does not allow a corporation to defend itself by showing that the employee's conduct violated its compliance policy or a directive from a superior,"29.

Beyond boards, organisations in general tend to rely on this development of vicarious liability law. Despite the disadvantages that this may present, both morally and legally, organisations do not hesitate to find loopholes. Recognizing that liability will be attached to the group and not to the individual acting in the name and on behalf of the group, various mechanisms are being implemented to limit individual management and favour group actions. Three objectives are therefore planned: collectivisation, mitigation and dilution.

Many modern management concepts help those three objectives:

a) Transition from management by a trusted representative to management by a board, which is perhaps an innovation that was born with the Dutch East India Company in the $17^{\text {th }}$ century $^{30}$ (and the very helpful rule of majority. However, directors sleep better with unanimity).

b) The concept, introduced by Peter Drucker, of management by objectives ${ }^{31}$. Executives must take actions to meet certain goals: therefore, every action can be justified by the importance of the "cause".

c) Shareholder democracy: asking the shareholders to absolve you by approving your actions (e.g. say-on-pay). This is not a very good deal for

\footnotetext{
${ }^{26}$ Plesch \& Blankenburg (2012),

${ }^{27}$ Greenberg \& Brotman (2014).

${ }^{28} \mathrm{Ibid}$.

${ }^{29}$ Ibid.

${ }^{30}$ Steensgaard (1982).

${ }^{31}$ Drucker (1954).
} 
them. They set executives so that they will not be needed to take every decision; they are interested in dividends, not politics. ${ }^{32}$

We further propose that the nature of corporate crime might makes it particularly to track down responsibility altogether, and maybe individual responsibility with further reason, for the very reason that the criminal system cannot follow an intention, but only the manifestation of an intention. Frustration has been expressed as to the small number of convictions actually issued in the wake of the 2007-2008 financial crises. One factor may be that although a very extensive set of rules existed even at the time, any executive worth its salt either knew these regulations very well, or could pay the right amount of money to obtain the right advice as to not to fall within the category that would trigger actual criminal responsibility and would necessarily require to be, simultaneously, strictly defined and construed according to the meta-rules of criminal law.

To illustrate this simple fact, let us provide a simple example: that of tax fraud. Taxation offers very straightforward incentives, as far as reward and punishment are concerned: the craft of the tax adviser is, first, to know what the exact rules of the game are; by careful examination of the tax code, the tax administration practice, the double tax treaties etc. and then to design a solution that would be as close to the criminal limit as possible. If then, the tax scheme is challenged by the judge, a certainly relevant defence would be to show the "homework" done in preparation of that fateful day, which fateful day any astute executive bears in a corner of his mind.

Another good example is offered by the narratives surrounding the brutal collapse of Lehman Brothers in 2008 after posting a record profit in 2007. The profit, it soon showed, was the proverbial castle built on sand, but the legal aspect was not so easy to shatter. The main chink in Lehman's armour was a scheme known as Repo 105: essentially, shortly before the end of each quarter (in other words, when the bank's results were due to be reported), Lehman Brothers would "sell" financial assets with the contractual provision that it would repurchase it, for a higher price, shortly after the quarter ended, which is of course tantamount to a loan from a financial standpoint; however, the aim of the bank was to qualify the repurchase agreement as a bona fide sale for accounting and reporting purposes ${ }^{33}$. Lehman's executives would not go with the scheme without securing a legal opinion, i.e. a letter issued by a renowned law firm opining as to the legality of the schemes, and, unsuccessfully in obtaining one from a law firm in the United States, they ended up with a legal opinion from the London branch of Linklaters LLC, thus acquiring a semblance of legality. When, furthermore, the position of the company had become so untenable that a sale appeared unavoidable the chief executive officer and public face of the company, Richard Fuld, publicly announced that he would refuse to sell it at too low of a price, then, in an equally vocal fashion, offered his resignation of his head were to be required as a sine qua non by prospective acquirers ${ }^{34}$. This of course begs the question: is it fairer to

\footnotetext{
${ }^{32}$ Cheffins \& Thomas (2001).

${ }^{33}$ Jeffers (2011).

${ }^{34}$ Fishman (2008).
} 
describe him as being ethical, keeping the best interest of his company above all, or as acting ethical, and being astute? As far as corporate crime is concerned, things always look simpler from afar.

There could be debate over whether individual members of boards of directors are more prone to irresponsible behaviour than the average. Estimations of psychopathic traits among executives necessarily involve some element of guesswork if only because voluntary subjection to an in-depth psychiatric evaluation would probably not be a popular idea among CEOs, furthermore, the lead article on the subject ${ }^{35}$ ends up with a wide range of estimation (between $4 \%$ and 20\%). However, Dutton notes a prevalence of psychopaths in civil service or among professions such as (unnervingly) lawyers. It is worth noting that legal scholars do not appear on Dutton's list.

We would above all emphasise that individual psychopathy of the leader of an organisation is not a shortcut to understand the deviant behaviour of the organisation itself. In 2014, the British government launched a programme aimed at recruiting psychopaths, because this population tends to present certain very desirable traits in terms of drive and organisation ${ }^{36}-$ it is even conceivable that ruthlessness, or extreme detachment from one's feelings may prove a very valuable trait in certain professions (which would likewise explain why Dutton ranks surgeons so highly on his list ${ }^{37}$ ). Another argument against the uniqueness of corporate board deviance would stem from the efficient-market hypothesis. Indeed, shareholders would eventually, if only by trial and error, avoid those executives whose criminal disposition would be excessive when compared to the benefits of ruthlessness, as the cost of civil suits and criminal fines would end up affecting the company's earnings. In general, it would be more logical for shareholders to prefer criminal fines imposed on the directors than on the company itself, and thus an interesting idea for further research would be to verify whether they, in actuality, favour those jurisdictions and company forms that effectively fit this criterion.

An even better example comes from the darker pages of history and from the dismal field of genocide studies. According to Dr Gregory Stanton, all genocides tend to follow the same pattern, the last element of which being denial - as a matter of fact, Stanton asserts that denial of genocide is a constant and that its continuation is a incontestable proof that genocidal activities are still occurring. However, the organisation of deniability starts much earlier in the process. According to Stanton himself, genocide is "often using militias to provide deniability of state responsibility" 38 . It has been observed that the very language used by the perpetrators is often intentionally vague and ambiguous, so as to make any future use of such language as evidence difficult. This tendency to euphemisation is noted by the seminal work on Third Reich phraseology, LTI Lingua Tertii Imperii by Victor Klemperer: for example, the otherwise abundant

\footnotetext{
${ }^{35}$ Brooks \& Fritzon (2016). The article was eventually retracted due to a plagiarism issue.

${ }^{36}$ Saul (2014).

${ }^{37}$ Dutton (2012).

${ }^{38}$ Stanton (1996).
} 
Nazi documentation evidencing the genocide of European Jews during the Second World War would use the following euphemisms

$(\text { Schleierwörter })^{39}$ :

Evakuierung (literally: "evacuation"): deportation

Konzentrationslager (lit.: "concentration camp"): extermination camp

Sonderbehandlung (lit.: "special treatment"): murder

Verschärfte Vernehmung (lit.:"intensified interrogation"): torture

As a matter of fact, the ubiquitousness of the "Special treatment" code word, instead of "murder", in Nazi documentation, was indeed used by Holocaust deniers after the war as a way negating the reality and magnitude of the crimes perpetrated by Germany ${ }^{40}$. Himmler was obsessive about the documentation of the Holocaust and imposed a further euphemisation: durchschleusen (literally, "to guide through"). Korherr had issued a report which Himmler praised for its discretion. However, he did receive the following observation:

"Der Reichsführer-SS hat Ihren statistischen Bericht über "Die Endlösung der europäischen Judenfrage" erhalten. Er wünscht, daß an keiner Stelle von "Sonderbehandlung der Juden" gesprochen wird. Auf Seite 9 muß es folgerndermaßen heißen:

"Transportierung von Juden aus den Ostprovinzen nach dem russichen Osten:

Es wurden durchgeschleust

durch die Lager im Generalgouvernement...

durch die Lager im Warthegau..."

Eine andere Formulierung darf nicht genommen werden...

[translation]:

"The Reichsführer-SS has received your report on "The Final Solution of the European Jewish Question". He wishes that "special treatment of the Jews" not be mentioned anywhere. On page 9, it must be formulated as follows:

"They were guided [through]

through the camps in the General Government

through the camps in the Warthegau

No other formulation is to be employed. ${ }^{41}$ " (Emphasis ours in all cases)

One final, and very telling example, can be found not in a genocide per se but in an alleged violation of international law. On November 1979, against the backdrop of the Islamic Revolution and the backlash generated by the decision, made by the United States Government, to welcome the Shah on their territory (in addition to the general hostility boiling under the new regime), a group whose members described themselves as the "Muslim Student Followers of the Imam's Policy", and not acting on behalf of the Iranian State, famously assaulted the United States Embassy, and took hostages among the diplomatic personnel. Deliberating on the merits of the action later filed by the United States, the International Court of Justice, notes perplexingly:

\footnotetext{
${ }^{39}$ Klemperer (1947).

${ }^{40}$ Schermer \& Grobman (2009).

${ }^{41}$ Kogon \& Langbein (1995).
} 


\begin{abstract}
"No suggestion has been made that the militants, when they executed their attack on the Embassy, had any form of official status as recognized "agents" or organs of the Iranian State. Their conduct in mounting the attack, overrunning the Embassy and seizing its inmates as hostages cannot, therefore, be regarded as imputable to that State on that basis. Their conduct might be considered as itself directly imputable to the Iranian State only if it were established that, in fact, on the occasion in question the militants acted on behalf of the State, having been charged by some competent organ of the Iranian State to carry out a specific operation. The information before the Court does not, however, suffice to establish with the requisite certainty the existence at that time of such a link between the militants and any competent organ of the State. ${ }^{42,}$
\end{abstract}

Therefore, it would look like the corporate / political strategy of distancing oneself from the crime worked, but the International Court of Justice actually finds a solution that is in equal parts elegant and profound. Building notably on Articles 22 ("The receiving State is under a special duty to take all appropriate steps to protect the premises of the mission against any intrusion or damage and to prevent any disturbance of the peace of the mission or impairment of its dignity") and 29 of the 1961 Vienna Convention to conclude that the Iranian Government had a positive obligation to take any "appropriate steps" to remedy the violation of international law at work at the American Embassy, demonstrating how a responsibility of the legal person could be justifiably demonstrated ${ }^{43}$.

Drawing inspiration from those examples international law, an intellectually satisfying justification of how criminal liability can be imposed on legal persons, in particular corporation. To illustrate this, Apel and Paternoster sketch a theory of "criminogenic corporate culture": one view possesses almost Rousseauist accents: good, educated people are encouraged are driven to crime by the culture of the corporation, another related view relies on the concept of assortative mating: subjects with unethical traits are themselves attracted to companies that are equally unethical $^{44}$. In other words, the corporation's culture, disconnected to any of its officer in particular serves at least as an enabler, and at worst as an enticer of criminal behaviour. The same idea of using "corporate culture" as a cornerstone of corporate criminal liability is also defended, albeit slightly less convincingly, in a report prepared by Allens Arthur Robinson for the attention of the United Nations Special Representative of the Secretary-General on Human Rights and Business. ${ }^{45}$

Professor Kent Greenfield argues that since corporations are to a very large extent acknowledged as persons (under US Law), they should be treated exactly as $\operatorname{such}^{46}$. Such a simplification would seem both unappealing and impractical to us. But the group does bear a lot of responsibilities that the individuals refuse.

\footnotetext{
${ }^{42}$ International Court of Justice, Case Concerning United States Diplomatic And Consular Staff In Tehran, Judgment of 24 May 1980.

${ }^{43}$ Ibid.

${ }^{44}$ Apel \& Paternoster (2009).

${ }^{45}$ Robinson (2008).

${ }^{46}$ Greenfield (2018)
} 


\section{Conclusion}

Liability is first of all assumed individually, insofar as each person is supposed to provide reparation for the harm he or she has caused. However, persons acting in legal life are not only natural persons. Alongside the latter, there are also legal persons, even though they are constituted by natural persons. In absolute terms, the legal person is fictitious, since it is set up by natural persons who act in its name and on its behalf on a daily basis. Curiously, while personal liability is completely based on the individual, the law has made provisions to limit the liability of the shareholders to their contribution to the share capital. Such a configuration of the pattern of liability is problematic and may lead corporate directors to take unethical decisions: in fact, regardless of what the law states, they are very skilled at minimising their legal exposure. There is therefore a kind of systematic, organised and planned irresponsibility in corporate governance. Legislators should review the liability regime in legal persons, and even more so in corporations, notably by taking corporate culture seriously. Even in the corporate context, steps could be taken to ensure that those who act are subject to the legal regime of individual liability but because of the dynamics of corporate life, the task appears, unfortunately, Sisyphean.

\section{References}

Apel, R. \& R. Paternoster (2009). 'Understanding "Criminogenic" Corporate Culture: What White-Collar Crime Researchers Can Learn from Studies of the Adolescent Employment-Crime Relationship' in S.S. Simpson and D. Weisburd (eds.), The Criminology of White-Collar Crime. New York: Springer.

Bechler, J. (1988). 'Are jails replacing the mental health system for the homeless mentally ill?' in Community Mental Health Journal 27:1-78.

Bishop, J. (1893). Bishop's New Criminal Law. Chicago: T.H. Flood \& Co.

Blackstone, W. (1770). Commentaries on the Laws of England. Oxford: Clarendon Press.

Bouloc, P. (2019). Droit pénal général. Paris: Dalloz

Brooks, N. \& K. Frizton (2016). 'Psychopathic personality characteristics amongst high functioning populations' in Crime Psychology Review 2:22-44.

Cass, R. (1976). 'Ignorance of the Law: A Maxim Reexamined' in William \& Mary Law Journal 17:671-699.

Cheffins, B. \& R. Thomas (2001). 'Should Shareholders Have a Greater Say Over Executive Pay?: Learning from the US Experience' in Journal of Corporate Law Studies 1:277-315.

Clarkson, C.M.V. (1988). 'Corporate Culpability' in 2 Web Journal of Current Legal Issues. http://webjcli.ncl.ac.uk/1998/isue2/clarkson2.html

Davies, P., Hopt, K., Nowak, R. \& G. van Solinge (2013). Corporate Boards in Law and Practice: A Comparative Analysis in Europe. Oxford: Oxford University Press.

Deakin, S., Johnston, A. \& B. Markesinis (2012). Markesinis and Deakin's Tort Law. 7th ed. Oxford: Oxford University Press.

Drucker, P. (1954). The Practice of Management. New York: Harper.

Dutton, K. (2012). The Wisdom of Psychopaths: What Saints, Spies, and Serial Killers Can Teach Us about Success. Portsmouth: Heinemann. 
Ewald, F. (2020). The Birth of Solidarity: The History of the French Welfare State. Durham: Duke University Press.

Fishman, S. (2008). 'Burning Down His House' in New York Magazine, November 27. https://nymag.com/news/business/52603/

Foucault, M. (1975). Surveiller et punir. Paris: Gallimard.

Greenberg, J. \& E. Brotma (2014). 'Strict Vicarious Criminal Liability For Corporations and Corporate Executives: Stretching the Boundaries Of Criminalization' in American Law Review 51:79-98.

Greenfield, K. (2018). Corporations Are People Too (And They Should Act Like It). New Haven: Yale University Press.

Herald (1970). 'Criminal Law: Alcoholism as a Defense' in Marquette Law Review. 53:445-450.

Ireland, P. (2010). 'Limited liability, shareholder rights and the problem of corporate irresponsibility', in Cambridge Journal of Economics 34:837-856.

Jeffers, A. (2011). 'How Lehman Brothers Used Repo 105 to Manipulate Their Financial Statements', in Journal of Leadership, Accountability and Ethics 8:44-55.

Klemperer, V. (1947). LTI - Lingua Tertii Imperii: Notizbuch eines Philologen. Leipzig: Reclam Verlag.

Kogon, E. Langbein, H. \& A. Rückerl (1995). Nationalsozialistische Massentötungen durch Giftgas: eine Dokumentation. Frankfurt am Main: Fischer Taschenbuch Verlag.

Kraakman, R., Hansmann, H., Pargendler, M., Hertig, G., Kanda H., \& P. Davies (2004). The Anatomy of Corporate Law: A Comparative and Functional Approach. Oxford: Oxford University Press.

Lieberman, B. (1927) 'Torts in Jewish Law' in Journal of Comparative Legislation and International Law 9:231-240.

Lombroso, C. (1911). Crime - Its Causes and Remedies. Boston: Little, Brown and Company.

Merle, P. (2020). Droit commercial : les sociétés commerciales. 23rd ed. Paris: Dalloz.

Plesch, D. \& S. Blankenburg (2012). 'Corporate Rights and Responsibilities: Restoring Legal Accountabilitye' in SOAS Research. https://www.soas.ac.uk/cisd/research/ma terial/file120296.pdf

Robinson, A.A. (2008). 'Corporate Culture' as a Basis for the Criminal Liability of Corporations'. Report to the United Nations Special Representative of the SecretaryGeneral on Human Rights and Business.

Saul, H. (2014). 'UK Government officials considered recruiting psychopaths 'to keep order' after nuclear attack'. The Independent, November 1. https://www.indepen dent.co.uk/news/uk/home-news/uk-government-considered-recruiting-psychopathsto-keep-order-after-nuclear-attack-9832910.html

Schermer, M. \& A. Grobman (2009). Denying history: who says the Holocaust never happened and why do they say it? Berkeley: University of California Press.

Stanton, H. (1996) 'The 8 Stages of Genocide'. Working paper presented of the Yale Program on Genocide Studies.

Steensgaard, N. (1982). "The Dutch East India Company as an Institutional Innovation", in Maurice Aymard (ed.), Dutch Capitalism and World Capitalism / Capitalisme hollandais et capitalisme mondial (Studies in Modern Capitalism / Etudes sur le capitalisme moderne), 235-257. Cambridge: Cambridge University Press.

Talbot, L. (2015). Critical Company Law. 2nd ed. Abingdon-on-Thames: Taylor \& Francis.

Terré, F., Simler P., Lequette Y. \& F. Chenedé (2018) Droit Civil : Les obligations. 12th ed. Paris: Dalloz. 


\section{Cases}

France

Cour de cassation - Chambre criminelle - 19/03/1997.

$U S A$

New York Central \& Hudson River Railroad Co. v. U.S, 22 Ill.212 U.S. 481, 29 S. Ct. 304, 53 L. Ed. 613 (1909).

United States v. Freed, 401 U.S. 601 (1971).

International Court of Justice

Case Concerning United States Diplomatic and Consular Staff In Tehran, Judgment of 24 May 1980. 
